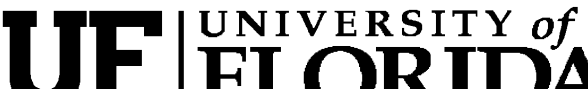 FLORIDA \\ IFAS Extension
}

\section{Florida's Environment - Central Region ${ }^{1}$}

\section{Martin B. Main and Ginger M. Allen²}

Florida's Environment series

\section{Introduction}

Florida's central region (Fig. 1) is characterized by diverse upland habitats and wetland systems. Conservation lands make up nearly one quarter of the regional land use (Table 1).

The Ocala National Forest is one of three national forests in Florida and encompasses most of the northern portion of this region (Fig. 2). Natural communities include large tracts of upland pine forest and scrub. To the south is Florida's lake country, sparkling with thousands of clear, natural lakes which host the largest concentration of bald eagles in the continental United States.

The Lake Wales Ridge, which forms an important part of Florida's central ridge system, was once a series of islands in a long-ago sea and now is home to Florida's ancient and critically-endangered scrub communities. West and south of the Kissimmee River basin are Florida's largest remaining dry prairie habitats. 


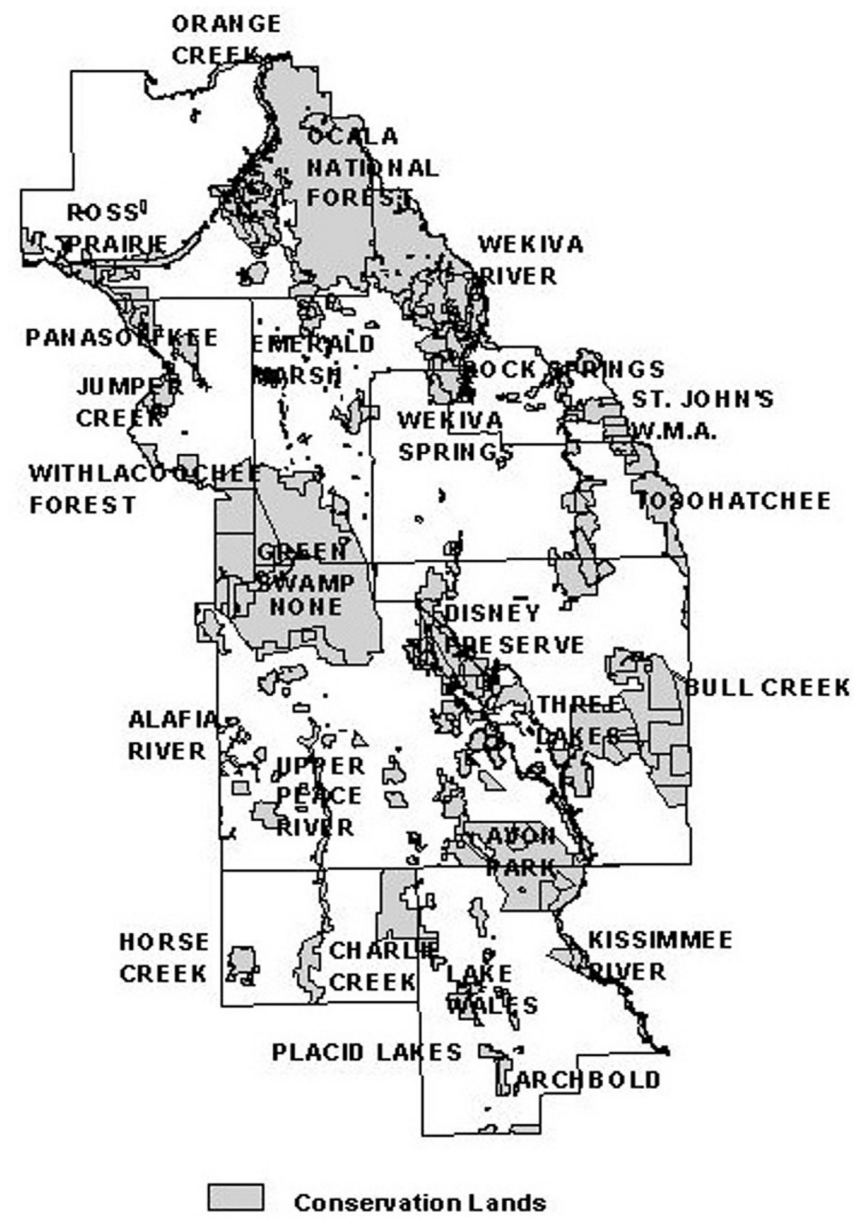

Figure 2. Central Florida major conservation lands. Credits: UF/IFAS

Table 1. Conservation land acreage in Florida's central region

\begin{tabular}{||c|c|c||}
\hline County & $\begin{array}{c}\text { Conservation } \\
\text { Land Acres }\end{array}$ & $\begin{array}{c}\text { \% of Total } \\
\text { County }\end{array}$ \\
\hline Hardee & 680 & $0 \%$ \\
\hline Highlands & 113,020 & $17 \%$ \\
\hline Lake & 191,620 & $31 \%$ \\
\hline Marion & 343,290 & $34 \%$ \\
\hline Orange & 83,880 & $14 \%$ \\
\hline Osceola & 159,530 & $19 \%$ \\
\hline Polk & 254,970 & $21 \%$ \\
\hline $\begin{array}{c}\text { Seminole } \\
\text { Sumter }\end{array}$ & 27,900 & $14 \%$ \\
\hline $\begin{array}{c}\text { Region } \\
\text { Total }\end{array}$ & $\mathbf{1 , 2 8 7 , 0 0 0}$ & $\mathbf{3 2 \%}$ \\
\hline $\begin{array}{c}\text { Based on 2006 Florida Natural Areas Inventory } \\
\text { Managed Conservation Lands. Florida State } \\
\text { University. }\end{array}$ & \\
\hline \hline
\end{tabular}

\section{Major Rivers, Lakes and Springs}

The rivers of central Florida drain the Lake Wales Ridge in all directions as they empty into various lakes and travel outside of the region into the Gulf of Mexico. Abundant springs originating from the Floridan aquifer dot the central landscape and give life to many of the rivers in the region.

The Oklawaha River flows 96 miles north from Lake Harris in Lake County to the St. Johns River, to which it is the principle tributary. The Oklawaha is one of the oldest rivers in Florida, and this gives it a variety of established habitats. Three dams, the Moss Bluff Dam, Eureka Dam, and Rodman Dam, alter the flow of the Oklawaha and create recreation areas. The river's water quality is tied to its source lakes, Lake Apopka and Lake Griffith.

The Peace River originates in the Green Swamp of Polk County and flows 105 miles before emptying into the Gulf of Mexico at Charlotte Harbor (Southwest Region). The Peace River has many tributary creeks and the land use along the banks is mainly agriculture.

The Palatlakaha River, one of Florida's most pristine and beautiful rivers, is more of a watercourse connecting several lakes than a true river. It is contained entirely within Lake County, originating from Lake Louisa and ending at Lake Harris.

Historically, the Kissimmee River coursed 98 miles between Lake Kissimmee and Lake Okeechobee. The river was channelized for flood control and navigation to a 56-mile-long canal by the early 1970s. The once extensive floodplain marshes were transformed into cattle pasture and the water cleansing ability of the river was lost, which increased nutrient loads entering Lake Okeechobee. During 1992 the Kissimmee River became the site of the largest river restoration project in the world, with plans to restore over 40 square miles of river/floodplain ecosystem including 43 miles of meandering river channel and 27,000 acres of wetlands. 
Designated an Outstanding Florida Water, a Wild and Scenic River, and an Aquatic Preserve, the Wekiva River is valued for its biological and archaeological resources, as well as for its pure water. The Wekiva is one of the steepest rivers in Florida. The banks and swamps along the Wekiva provide important bird rookeries and wildlife habitats.

Silver Springs is Florida's third largest spring and it has been made famous by movies and television. Visitors come enjoy glass-bottom boat tours, crystal clear waters, and constant water temperatures of $72^{\circ}$ F. Rainbow Springs, Silver Glen Springs, Alexander Springs, and Wekiwa Springs are also popular recreational spots.

Lake Apopka is found in the headwaters of the Ocklawaha River in Lake and Orange counties. In 1941, a levee was built along the north shore to drain 20,000 acres of shallow marsh for farming. During 1947 citrus and muck farming wastes were discharged into the lake, which resulted in algae blooms and fish kills, and by the mid-1950s fish populations were greatly reduced. Water hyacinth invaded the lake in 1959 and replaced native eelgrass and pondweed by the early 1970s. Treated wastewater was discharged into the lake from shoreline communities until the 1980s. Agricultural discharge laden with phosphorous continued until the early 1990s. Lake Apopka was targeted for restoration by St. Johns Water Management District in partnership with local state and federal agencies in 1985. Lake Apopka's water quality has improved in response to these conservation efforts. Phosphorous levels are down 62 percent and water clarity has improved by 68 percent. Future improvements are anticipated as more former farms on the lake's north shore are reflooded.

Lake Istokpoga (27,692 acres) is located northeast of Lake Placid in Highlands County. Lake Istokpoga is highly known for high quality black crappie and large mouth bass fishing.

Lake Kissimmee, Florida's third largest lake, encompasses 35,000 acres in Osceola County. The lake and its surrounding area hosts over 200 species of birds making it one of the best birding areas in central Florida. A 1996 lake drawdown and habitat enhancement project has led to a great increase in large mouth bass populations.
Lake Panasoffkee, located in Sumter County, is a lake/swamp hybrid. Many acres of forested swamp occur within the lake, which drains into the Withlacoochee River. The lake is a popular fishing spot and it is a major wintering ground for migratory waterfowl.

Lake Griffin, located in Lake County, is also a popular fishing and birding location. "Marsh islands" occasionally appear in the lake, which are created by floating chunks of marsh vegetation that break off from the adjacent marsh habitat and float iceberg-like into the lake.

\section{Featured Natural Areas}

(see Table 2 for detailed list of natural areas)

Ocala National Forest covers approximately 389, 000 acres in central Florida. Established in 1908, it is the oldest National Forest east of the Mississippi River and the southernmost National Forest in the continental U.S. This huge area includes scrub and various other upland habitats, as well as all manner of wetlands.

Wekiwa Springs State Park is a sandhill community located near Apopka. Barred owls and pileated woodpeckers are common in the cabbage palm-oak hammocks near the river. Sand pine scrub occurs near the picnic area and is home to a number of Florida rarities, including the Florida mouse, worm-lizard, and crowned snake. Sandhills, scrub, flatwoods, hammocks, and swamps support black bear and many other species of wildlife.

Archbold Biological Station, in Highlands County, is a 5,000 acre privately-owned property that supports an active research program dedicated to understanding and conserving species and habitats--particularly scrub-of the Lake Wales Ridge.

\section{Nature Conservancy Tiger Creek Preserve} encompasses 4,805 acres on the edge of Florida's oldest and highest landmass, the Lake Wales Ridge. Tiger Creek Preserve is named after the pristine blackwater stream within the preserve, almost all of which is protected as well as its surrounding hardwood swamps, hammocks, oak scrub, pine 
flatwoods, sandhill, and longleaf pine/wiregrass habitats. Rare animals and plants live in the preserve, some of which occur nowhere else on Earth.

Highlands Hammock State Park preserves a virgin hardwood forest and also includes cypress swamp, pine flatwoods, sand pine scrub, scrubby flatwoods, bayheads, and marsh habitats. Three boardwalks provide easy access to forested habitats.

Avon Park Air Force Range manages unique and endangered central Florida habitats including dry prairie, oak and sand pine scrub, and seepage slopes. Pine flatwoods, marshes, and hardwood hammocks also occur. Hunting and other recreational opportunities exist.

Lake Kissimmee State Park was once used by Native Americans because of the abundance of fish and game in the area. Habitats include floodplain forests, hardwood hammocks, oak scrub, and longleaf pine communities. Lake Kissimmee State Park hosts over two hundred species of birds making it one of the best birding areas in central Florida.

\section{Cultural History}

Prehistoric Indian sites, middens (trash heaps), and mounds (burial sites), are found along many of central Florida's rivers. For example, the Oklawaha River, Arbuckle Creek, and the Wekiwa, all have archeological sites.

A look back at the region's history in the area gives evidence of changing land. For example, the land that is now Lake Kissimmee State Park was once used by Native Americans because of the abundance of fish and game in the area. During the third Seminole War Fort Gardiner was built near Lake Kissimmee as a temporary fortification. Later the area was widely used for timber and turpentine. During the Civil War the area was used for raising cattle that were shipped to the Confederate Army or traded with Cuba for supplies. After the war cattle ranching became the primary industry in the area and remains an important industry today.

A short drive to the east of Silver Springs is the Juniper Prairie wilderness area. The Long family, characterized in Marjorie Kinnan Rawlings' famous book, "The Yearling," settled Pats Island around 1840. The character and history of the area are captured in Rawling's writing, and visitors can still visit many of the places described in her book.

\section{Additional Sources of Information}

\section{Published Resources}

Allen, G.M. and M.B. Main. 2005. Florida's Geological History. Fact Sheet WEC 189, Department of Wildlife Ecology and Conservation, Florida Cooperative Extension Service, Institute of Food and Agricultural Sciences, University of Florida. http://edis.ifas.ufl.edu.

Burt, A., Jr. 1999. The Tropic of Cracker (The Florida History and Culture Series), University Press of Florida, Gainesville, FL.

Carter, E. F., L. Glaros, and D. Sphar 1985. A Canoeing And Kayaking Guide To The Streams Of Florida, Volume II, Central And South Peninsula. Menasha Ridge Press, Birmingham, Alabama.

Cerulean, S. and A. Morrow. 1998. Florida Wildlife Viewing Guide. Falcon Publishing. Helena, MT.

Fernald, E. A. and E. D. Prudum, eds. 1998. Water Resources Atlas of Florida. Institute of Science and Public Affairs. Tallahassee, FL.

Florida Department of Natural Resources. 1989. Florida Rivers Assessment. Florida Department of Natural Resources. Tallahassee, FL.

Gannon, M., ed. 1996. The New History of Florida. Univ. Press of Florida. Gainesville, FL.

Jewell, S. D. 1995. Exploring Wild Central Florida : A Guide to Finding the Natural Areas and Wildlife of the Central Peninsula. Pineapple Press, Sarasota, FL.

Karim, A. and M.B. Main. 2004. Tropical Hardwood Hammocks in Florida. Fact Sheet WEC 181, Department of Wildlife Ecology and Conservation, Florida Cooperative Extension 
Service, Institute of Food and Agricultural Sciences, University of Florida. http://edis.ifas.ufl.edu.

Kavanagh, J. ed. 1997. The Nature of Florida : An Introduction to Common Plants \& Animals \& Natural Attractions (Field Guides Series) Waterford Press, Phoenix, AZ.

Kleinberg, E. 1997. Historical Traveler's Guide to Florida. Pineapple Press, Sarasota, FL.

Laurie M., and D. Bardon. 1998. Florida's Museums and Cultural Attractions. Pineapple Press, Sarasota, FL.

Main M.B., and G.M. Allen. 2005. Florida State Symbols. Circular 1467, Department of Wildlife Ecology \& Conservation, Florida Cooperative Extension Service, Institute of Food and Agricultural Sciences, University of Florida. http://edis.ifas.ufl.edu.

Main M.B. , M.E. Swisher, J. Mullahey, W. DeBusk, A. J. Shriar, G. W. Tanner, J. Selph, P. Hogue, P. Bohlen and G. M. Allen. 2004. The Ecology and Economics of Florida's Ranches. Fact Sheet WEC 187, Wildlife Ecology and Conservation Department, Florida Cooperative Extension Service, Institute of Food and Agricultural Sciences, University of Florida. http://edis.ifas.ufl.edu.

Main M.B., and G.W. Tanner. 1999. Effects of Fire on Florida's Wildlife and Wildlife Habitat. Fact Sheet WEC 137, Department of Wildlife Ecology \& Conservation, Florida Cooperative Extension Service, Institute of Food and Agricultural Sciences, University of Florida. http://edis.ifas.ufl.edu.

Meyers, Ronald L. \& John J. Ewel, eds. 1990. Ecosystems of Florida. University of Central Florida Press. Orlando, FL.

Milanich, J. T. 1998. Florida Indians from Ancient Times to the Present. University of Florida Press. Gainesville, FL.

Milanich, Jerald T. 1995. Florida Indians and the Invasion from Europe. University of Florida Press. Gainesville, FL.
Ohr, T. 1998. Florida's Fabulous Natural Places. World Publications, Tampa, FL.

Perry J., and J. G. Perry 1992. The Sierra Club Guide to the Natural Areas of Florida. Sierra Club Books, San Francisco, CA.

Ripple, J. 1997. Florida: The Natural Wonders. Voyageur Press, Osceola, WI.

Rosenau, J.C., G.L. Faulkner, C.W. Hendry, Jr., and R.W. Hull. 1977. Springs of Florida. Geological Bulletin No. 31. Department of Natural Resources, Bureau of Geology. Tallahassee, FL.

Stamm D., and D. R. Stamm. 1998. The Springs of Florida. Pineapple Press, Sarasota, FL.

Winsberg, M. D. 1997. Florida's History Through Its Places: Properties in the National Register of Historic Places, University Press of Florida, Gainesville, FL.

\section{Online Resources}

Camping in Central Florida, http://www.gorp.com/gorp/publishers/foghorn/ cam_fl6.htm

Emeralda Marsh Journal, http://www.stetson.edu/ pmay/emeralda/

Florida Division of Historical Resources, http://www.flheritage.com/

Florida Fish \& Wildlife Commission Wildlife Viewing Sites, http://www.myfwc.com/viewing/

Florida's Historic Places, http://fcit.coedu.usf.edu/florida/lessons/places.htm

Florida's Museum of Natural History, http://www.flmnh.ufl.edu/

Florida Natural Areas Inventory, http://www.fnai.org

Florida's Scenic Highways, http://www.dot.state.fl.us/emo/scenichwy/default.htm

Florida State Parks, http://www.floridastateparks.org/ 
Florida Water Management Districts, http://dlis.dos.state.fl.us/fgils/wmd.html

P.K. Yonge Library of Florida History, http://web.uflib.ufl.edu/spec/pkyonge/index.html

Visit Florida, http://www.visitflorida.com 
Table 2. Recreational and cultural opportunities in natural areas in central Florida

\begin{tabular}{|c|c|c|c|}
\hline County & Natural Area & Phone & Web site \\
\hline Hardee & $\begin{array}{l}\text { Paynes Creek State } \\
\text { Historic Site }\end{array}$ & $(941) 375-4717$ & http://www.floridastateparks.org/paynescreek/ \\
\hline Highlands & $\begin{array}{l}\text { Avon Park Air Force } \\
\text { Range }\end{array}$ & (863) $452-4254$ & http://myfwc.com/viewing/sites/site-c20.html \\
\hline Highlands & $\begin{array}{l}\text { Highlands Hammock } \\
\text { State Park }\end{array}$ & (863) 386-6094 & $\begin{array}{l}\text { http://www.floridastateparks.org/ } \\
\text { highlandshammock/ }\end{array}$ \\
\hline Highlands & $\begin{array}{l}\text { Archbold Biological } \\
\text { Station }\end{array}$ & (863) 465-2571 & http://www.archbold-station.org/ \\
\hline Highlands & Buck Island & (863) 465-2571 & http://www.archbold-station.org/ \\
\hline Highlands & Lake Istokpoga & (863) 648-3202 & http://www.jimporter.org/lakes/istokpoga/ \\
\hline Lake & $\begin{array}{l}\text { Emeralda Marsh } \\
\text { Conservation Area }\end{array}$ & (407) 893-3127 & $\begin{array}{l}\text { http://sjr.state.fl.us/programs/outreach/pubs/ } \\
\text { recguide/w01_emeralda_marsh_CA.html }\end{array}$ \\
\hline Lake & Blue Springs State Park & (904) 775-3663 & http://www.floridastateparks.org/bluespring/ \\
\hline Lake & Lake Louisa State Park & (352) 394-3969 & http://www.floridastateparks.org/lakelouisa/ \\
\hline Lake & Lake Griffin State Park & (352) 360-6760 & http://www.floridastateparks.org/lakegriffin/ \\
\hline Lake & $\begin{array}{l}\text { Lake Apopka } \\
\text { Restoration Area }\end{array}$ & (904) 329-4500 & $\begin{array}{l}\text { http://sjr.state.fl.us/programs/outreach/pubs/ } \\
\text { recguide/w02 lake apopka RA.html }\end{array}$ \\
\hline Lake & Seminole State Forest & (352) $360-6675$ & http://www.fl-dof.com/state forests/seminole.html \\
\hline Marion & $\begin{array}{l}\text { Ocklawaha Prairie } \\
\text { Restoration Area }\end{array}$ & $(407) 893-3127$ & $\begin{array}{l}\text { http://sjr.state.fl.us/programs/acq_restoration/ } \\
\text { s_water/uockr/ockprairie.html }\end{array}$ \\
\hline Marion & $\begin{array}{l}\text { Juniper Prairie } \\
\text { Wilderness }\end{array}$ & $(850) 523-8500$ & $\begin{array}{l}\text { http://www.fs.fed.us/r8/florida/recreation/ } \\
\text { index oca.shtml\#juniper }\end{array}$ \\
\hline Marion & Ocala National Forest & (850) 523-8500 & $\begin{array}{l}\text { http://www.fs.fed.us/r8/florida/recreation/ } \\
\text { index_oca.shtml }\end{array}$ \\
\hline Marion & Silver River State Park & (352) 236-1827 & $\begin{array}{l}\text { http://www.floridastateparks.org/silverriver/ } \\
\text { default.cfm }\end{array}$ \\
\hline Orange & $\begin{array}{l}\text { Lower Wekiva River } \\
\text { State Preserve }\end{array}$ & (407) 884-2008 & $\begin{array}{l}\text { http://www.floridastateparks.org/lowerwekivariver/ } \\
\text { default.cfm }\end{array}$ \\
\hline Orange & $\begin{array}{l}\text { Rock Springs Run State } \\
\text { Reserve }\end{array}$ & & $\begin{array}{l}\text { http://www.floridastateparks.org/rockspringsrun/ } \\
\text { default.cfm }\end{array}$ \\
\hline Orange & $\begin{array}{l}\text { Disney Wilderness } \\
\text { Preserve }\end{array}$ & (407) 935-0002 & $\begin{array}{l}\text { http://nature.org/wherewework/northamerica/states/ } \\
\text { florida/preserves/art5523.html }\end{array}$ \\
\hline Orange & Forever Florida & (866) 854-3837 & http://www.floridaeco-safaris.com/index.php \\
\hline Orange & $\begin{array}{l}\text { Split Oak Forest } \\
\text { Mitigation Park }\end{array}$ & & $\begin{array}{l}\text { http://www.floridaconservation.org/recreation/ } \\
\text { split_oak/visitorinfo.asp }\end{array}$ \\
\hline Orange & Tibet-Butler Preserve & (407) 876-6696 & $\begin{array}{l}\text { http://www.floridaconservation.org/viewing/sites/ } \\
\text { site-c07.html }\end{array}$ \\
\hline Orange & $\begin{array}{l}\text { Three Lakes Wildlife } \\
\text { Mgmt. Area }\end{array}$ & (407) 436-1818 & http://myfwc.com/viewing/sites/site-c16.html \\
\hline Orange & $\begin{array}{l}\text { Econlockhatchee River } \\
\text { Canoe Trail }\end{array}$ & (850) 488-3701 & $\begin{array}{l}\text { http://www.dep.state.fl.us/gwt/guide/regions/ } \\
\text { eastcentral/trails/econlockhatchee.htm }\end{array}$ \\
\hline Orange & West Orange Trail & (407) 654-5144 & $\begin{array}{l}\text { http://www.dep.state.fl.us/gwt/guide/regions/ } \\
\text { eastcentral/trails/west orange.htm }\end{array}$ \\
\hline Orange & $\begin{array}{l}\text { William Beardall } \\
\text { Tosohatchee State } \\
\text { Reserve }\end{array}$ & (407) 568-5893 & $\begin{array}{l}\text { http://www.visitflorida.com/destinations/ } \\
\text { moreinfo.php/ID=8035/detail=park }\end{array}$ \\
\hline Osceola & $\begin{array}{l}\text { Disney Wilderness } \\
\text { Preserve, The }\end{array}$ & (407) 935-0002 & http://www.tnc.org \\
\hline
\end{tabular}


Table 2. Recreational and cultural opportunities in natural areas in central Florida

\begin{tabular}{|c|c|c|c|}
\hline County & Natural Area & Phone & Web site \\
\hline Osceola & $\begin{array}{l}\text { Lower Reedy Creek } \\
\text { Management Area }\end{array}$ & & $\begin{array}{l}\text { https://my.sfwmd.gov/portal/page?_pageid=2236, } \\
\text { 4736096\&_dad=portal\&_schema=PORTAL }\end{array}$ \\
\hline Osceola & $\begin{array}{l}\text { Lake Kissimmee State } \\
\text { Park }\end{array}$ & (863) 696-1112 & $\begin{array}{l}\text { http://www.floridastateparks.org/lakekissimmee/ } \\
\text { default.cfm }\end{array}$ \\
\hline Osceola & East Lake Tohopekaliga & (407) 957-7243 & http://www.toptenlakes.com/lake tohopekaliga.htm \\
\hline Osceola & Three Lakes WMA & (352) $732-1225$ & http://myfwc.com/recreation/three_lakes/default.asp \\
\hline Polk & Lake Weohyakapka & (850) 488-4676 & http://www.toptenlakes.com/lake_weohyakapka.htm \\
\hline Polk & $\begin{array}{l}\text { Arbuckle Wildlife Mgmt. } \\
\text { Area }\end{array}$ & (407) 635-7801 & http://myfwc.com/viewing/sites/site-c19.html \\
\hline Polk & $\begin{array}{l}\text { Bok Tower Pine Ridge } \\
\text { Trail }\end{array}$ & (863) 676-1408 & http://www.boktower.org/index.html \\
\hline $\begin{array}{l}\text { Polk \& } \\
\text { Highlands }\end{array}$ & $\begin{array}{l}\text { Nature Conservancy } \\
\text { Tiger Creek Preserve }\end{array}$ & (407) 682-3664 & $\begin{array}{l}\text { http://www.nature.org/wherewework/northamerica/ } \\
\text { states/florida/preserves/art5524.html }\end{array}$ \\
\hline Seminole & Cross Seminole Trail & (407) 869-5966 & $\begin{array}{l}\text { http://www.dep.state.fl.us/gwt/guide/regions/ } \\
\text { eastcentral/trails/cross_seminole.htm }\end{array}$ \\
\hline Seminole & $\begin{array}{l}\text { Little Big Econ State } \\
\text { Forest }\end{array}$ & (407) 971-3500 & $\begin{array}{l}\text { http://www.fl-dof.com/state_forests/ } \\
\text { little big econ.html }\end{array}$ \\
\hline Sumter & $\begin{array}{l}\text { Dade Battlefield State } \\
\text { Historic Site }\end{array}$ & (904) 793-4781 & $\begin{array}{l}\text { http://www.floridastateparks.org/dadebattlefield/ } \\
\text { default.cfm }\end{array}$ \\
\hline Sumter & $\begin{array}{l}\text { Withlacoochee State } \\
\text { Forest }\end{array}$ & (352) 754-6777 & $\begin{array}{l}\text { http://www.fl-dof.com/state_forests/ } \\
\text { withlacoochee.html }\end{array}$ \\
\hline
\end{tabular}

